\title{
Survey of ornamental plants functioned as medicinal plants at some ornamental gardens in Ho Chi Minh City and applying them in garden design
}

Tien T. M. Duong*, \& Phuc T. Le

Faculty of Environment and Natural Resources, Nong Lam University, Ho Chi Minh City, Vietnam

ARTICLE INFO
Research Paper
Received: November 19, 2018
Revised: April 10, 2019
Accepted: May 02, 2019
Keywords
Garden design
Medicinal ornamental garden
Medicinal plants
Ornamental herb garden
Ornamental plants
*Corresponding author
Duong Thi My Tien
Email: duongmytien@hcmuaf.edu.vn

\begin{abstract}
The objective of the study was to identify some of common ornamental plants functioned as medicinal plants. The study was carried out in the Ho Chi Minh City, from September 2016 to June 2018 using some methods such as survey, identification, statistics, and applying these plants in garden design with site analysis, computer-aided design and drafting base on main idea. One hundred and twenty popular species belonging to 69 families with medicinal values were identified. Two cases for concept design, instant tree list, shrub and cover list were also proposed. The completed design drawings included function layout plan, master plan, sections and some details of garden, master perspective, detailed perspectives.
\end{abstract}

Cited as: Duong, T. T. M., \& Le, P. T. (2019). Survey of ornamental plants functioned as medicinal plants at some ornamental gardens in Ho Chi Minh City and applying them in garden design. The Journal of Agriculture and Development 18(5), 87-97. 


\title{
Khảo sát các cây cảnh có giá trị dược liệu tại một số vườn kiểng ở Thành phố Hồ Chí Minh và ứng dụng trong thiết kế sân vườn
}

\author{
Dương Thị Mỹ Tiên* \& Lê Thị Phúc
}

Khoa Môi Trường và Tài Nguyên, Trường Đại Học Nông Lâm TP.HCM, TP. Hồ Chí Minh

\section{THÔNG TIN BÀI BÁO}

\section{Bài báo khoa học}

Ngày nhận: 19/11/2018

Ngày chỉnh sửa: 10/04/2019

Ngày chấp nhận: 02/05/2019

\section{Từ khóa}

Cây cảnh

Cây cảnh dược liệu

Cây dược liệu

Thiết kế sân vườn

Vườn cảnh quan cây dược liệu

*Tác giả liên hệ

Dương Thị Mỹ Tiên

Email: duongmytien@hcmuaf.edu.vn

\section{TÓM TẮT}

Đề tài được tiến hành tại Thành phố Hồ Chí Minh trong thời gian từ tháng 9 năm 2016 dến tháng 6 năm 2018, với mục tiêu nhận dạng một số cây cảnh phổ biến có giá trị dược liệu. Đề tài được thực hiện bằng phương pháp điều tra và khảo sát cây cảnh tại các vựa kiểng và vườn ươm, định danh cây đã điều tra, thống kê, phân tích dữ liệu và ứng dụng trong thiết kế sân vườn với các phương pháp đánh giá hiện trạng khu vườn, thể hiện ý tưởng thiết kế chi tiết bằng việc sử dụng các phần mềm thiết kế cảnh quan. Đề tài điều tra được 120 loài thuộc 69 họ thực vật có dược tính, ứng dụng thiết kế 2 trường hợp sân vườn, với hồ sơ thiết kế ý tưởng, đề xuất danh mục cây xanh, vật liệu, thiết bị sử dụng trong thiết kế, thuyết minh thiết kế chi tiết. Đồ án hoàn thành được các bản vẽ: mặt bằng phân khu chức năng, mặt bằng tổng thể, các mặt bằng cây xanh, mặt cắt, các chi tiết của sân vườn và phối cảnh tổng thể cũng như phối cảnh các phân khu, các tiểu cảnh làm điểm nhấn.

\section{1. Đặt Vấn Đề}

Việt Nam được đánh giá là một trong những nước có tiềm năng lớn về cây dược liệu trong khu vực Đông Nam Á (Thu, 2017) với khoảng 3.780 loài chiếm $11 \%$ trong số 35.000 loài cây dược liệu được biết trên thế giới (Tran \& ctv., 2016). Dân tộc Việt Nam có truyền thống lâu đời trong việc sử dụng các loài cây để làm thuốc thông qua việc tích lũy kinh nghiệm dân gian, sự sưu tầm ghi chép của nhiều thầy thuốc (Do, 2004) và với quan niệm nổi tiếng "Nam dược trị nam nhân" bên cạnh sự vận động người dân trồng cây dược liệu trong vườn nhà của danh y Tuệ Tĩnh. Ngoài dược tính, cây dược liệu còn có giá trị làm đẹp cho khung cảnh nhà vườn được ghi nhận như hình dáng, màu sắc, kết cấu, mùi thơm... như những loài cây cảnh quan khác. Do đó, trong những năm gần đây, nhu cầu sử dụng cây dược liệu trang trí không gian sống kết hợp với mục đích bảo vệ sức khỏe con người đang ngày một tăng cao, cây cảnh không chỉ cho ta nhìn thấy vẻ đẹp và hương thơm mà đó còn là những vị thuốc quý để chữa bệnh.

Nghiên cứu này nhằm mục tiêu khảo sát và thống kê những loài cây cảnh quan hiện đang được ươm tạo và buôn bán trên thị trường cây cảnh của TP. Hồ Chí Minh có giá trị làm thuốc chữa bệnh và đề xuất trồng những loài này trong thiết kế sân vườn để tạo ra tính đa dụng cho chức năng của khu vườn nhà phố.

Dựa trên một số tài liệu tra cứu và nhận diện cây cảnh trong và ngoài nước của các tác giả như Pham (2002) trong từ điển về cây cỏ Việt Nam. Le \& Pham (1993) đã chia cây trồng đô thị gồm cây bóng mát thuộc 4 nhóm (cây bóng mát có hoa đẹp, cây bóng mát có hoa thơm, cây bóng mát ăn quả, cây bóng mát thường) và cây trang trí thuộc 9 nhóm (cây họ tre trúc, cây họ cau dừa, cây cảnh 
dáng đẹp, cây cảnh hoa đẹp, cây cảnh quả đẹp, cây cảnh leo giàn, cây hàng rào, cây viền bồn, cây hoa). Tran (1998) phân loại cây xanh - cây cảnh thành 8 nhóm bao gồm các nhóm cây xanh đường phố (cây bóng mát), nhóm cây gỗ thân cột làm cảnh, nhóm cây leo làm cảnh, nhóm cây thân mọng nước làm cảnh, nhóm cây làm bonsai, nhóm cây có lá làm cảnh, nhóm cây có hoa làm cảnh, nhóm cây có quả và nước làm cảnh. Min \& ctv. (2003) đã điều tra và thống kê được hơn 1.200 loài cây xanh hoa cảnh ở Singapore về dặc điểm thực vật, nhu cầu nước tưới, ánh sáng và độ ẩm của các loài cây cảnh.

Về cây dược liệu, Pham \& ctv. (2000) đã đề cập đến hầu hết các cây dược liệu được xác minh và nghiên cứu biết rõ hoạt chất hoặc theo kinh nghiệm đã được đúc kêt, khoảng trên 700 cây dược liệu đã được ghi nhận, đồng thời 327 cây dược liệu phổ biến trong thực tế cũng như các bài thuốc kèm theo để tham khảo sử dụng. Với số lượng cây dược liệu phong phú hơn, Do (2004) đã định danh, mô tả các cây dược liệu và trình bày tác dụng dược lý, công dụng kèm theo của 901 cây dược liệu, phân chia thành 20 nhóm công dụng với các bảng tra cứu hình ảnh của 249 cây dược liệu khác nhau và các bảng tra cứu cây dược liệu xếp theo họ thực vật, cây dược liệu theo vị thuốc và hoạt chất theo tên Việt Nam, theo danh pháp khoa học. Sau đó, Vo (2012) đã phản ánh hầu hết thực tế phong phú của cây dược liệu ở Việt Nam thông qua những nghiên cứu cá nhân, cùng với những công trình khoa học viết về thực vật học và dược học cùng với những sự tìm hiểu từ các lương y ở nhiều địa phương trong cả nước.

Về sự phối hợp của chức năng dược liệu và làm cảnh, Dung (2017) đã mô tả 100 cây cảnh đẹp làm thuốc và kèm theo mỗi cây cảnh là một số vị thuốc sử dụng chính cây cảnh đó để chữa bệnh. Ngoài ra, trong một tài liệu khác, tác giả này cũng liệt kê 56 loài cây dược liệu làm cảnh phổ biến trong nhà trường và nêu công thức làm 21 loại nước giải khát từ quả và lá cây giúp phòng và chữa bệnh (Nguyen, 2003a). Nghiên cứu của Abdullah (2015) về xác định cây cảnh có chức năng dược liệu dựa trên hình dạng lá, kết cấu và màu sắc của nó cũng cho thấy tầm quan trọng của cây cảnh có dược tính. Trong thực tế, mô hình kinh doanh vườn ươm cây cảnh có giá trị dược liệu tại Đà Lạt mang về lợi nhuận lớn, chứng tỏ người dân rất quan tâm đến sự đa dụng của cây cảnh (Gia, 2016). Đây là nền tảng để đề tài được tiến hành.

\section{Vật Liệu và Phương Pháp Nghiên Cứu}

Khảo sát cây cảnh có giá trị dược liệu được thực hiện tại các vườn kiểng, vựa kiểng ở những khu vực tập trung trồng, sản xuất và buôn bán hoa kiểng sầm uất của TP. Hồ Chí Minh như làng hoa Gò Vấp là trung tâm giao dịch hoa cây cảnh (Dung, 2017), làng nghề hoa kiểng Thủ Đức có khoảng 90,05 ha vào năm 2015 với các chủng loại như mai, lan, bonsai kiểng cổ, kiểng lá (TDPC, 2016). Ngoài ra, các quận 7, 10 và Tân Bình cũng có những khu vực, những con đường chuyên sưu tập và kinh doanh cây hoa kiểng nổi tiếng, là địa chỉ mà người dân mỗi khi có nhu cầu trồng hoa cảnh hay đến lựa chọn.

Các vườn kiểng được lựa chọn theo phương pháp chọn mẫu ngẫu nhiên đơn giản. Đối tượng khảo sát là cây cảnh. Khảo sát được thực hiện thông qua mẫu phiếu khảo sát. Mỗi phiếu khảo sát là 1 vựa kiểng. Tổng số lượng phiếu khảo sát là 98 phiếu. Khảo sát tất cả các cây có tại vườn kiểng được chọn. Nội dung phiếu khảo sát gồm 2 phần: phần 1 là các thông tin về vựa kiểng (tên vựa, địa chỉ, tên chủ vựa kiểng, ngày khảo sát) và phần 2 về cây kiểng (tên cây thông thường, đặc điểm cây kiểng thân, lá, hoa, quả, giá bán). Hình thức khảo sát là tiến hành hỏi, quan sát, chụp ảnh, lấy mẫu và ghi chép: (i) Chụp ảnh cả cây, chụp riêng hoa, lá, quả và ghi chú mã số hình ảnh vào phiếu khảo sát; (ii) Lấy mẫu cây cảnh để ép mẫu lưu trữ và tra cứu.

Công tác nội nghiệp chính là định danh loài cây và dược tính bằng dùng những hình ảnh chụp được và mẫu ép để đối chiếu các đặc điểm hình thái xác định tên loài, họ thực vật bằng các tài liệu tra cứu như Cây cỏ Việt Nam (Pham, 2002) và Cây xanh và cây cảnh Sài Gòn (Tran, 1998), Từ Điển Cây Thuốc Việt Nam (Vo, 2012),... Sau đó, lập danh sách và thống kê các dữ liệu thu thập được, tính tần số, tần suất và tỷ lệ (\%) các kết quả điều tra và khảo sát... thiết lập các bảng thống kê, vẽ biểu đồ so sánh.

Với hai công trình sân vườn, tác giả đã khảo sát hiện trạng bằng các phương pháp chụp ảnh công trình từ nhiều hướng, quan sát địa hình, tham khảo bản đồ, hướng giao thông và vị trí khu đất, khảo sát công trình liên quan xung quanh khu đất thiết kế, tham khảo ý kiến chủ đầu tư sau đó tổng hợp thông tin và phân tích, đánh giá hiện trạng thiết kế. Các bước thiết kế được thực hiện gồm phân tích thiết kế, tìm ý tưởng, và thể hiện bằng các phần mềm đồ họa chuyên ngành như: 
AutoCad, Sketchup và Photoshop.

\section{Kết Quả và Thảo Luận}

\subsection{Số lượng vườn kiểng và số lượng loài}

Khảo sát 98 vườn kiểng ở TP. Hồ Chí Minh, trong đó ở Gò Vấp có 48 vườn kiểng (49\%), ở quận 7 có 13 vườn kiểng (13,2\%), quận Tân Bình có 5 vườn kiểng $(5,1 \%)$, quận 10 có 17 vườn $(17,3 \%)$ và quận Thủ Đức có 15 vườn kiểng $(15,3 \%)$. Các vườn kiểng được khảo sát ở 5 quận có phân bố tập trung để phát triển thành các khu chuyên kinh doanh cây cảnh, tạo điều kiện thuận lợi cho việc chọn mua cây cảnh của người dân. Đề tài đã định danh được 220 loài cây xanh hoa kiểng thuộc 81 họ thực vật trong đó có 120 loài có giá trị dược liệu thuộc 69 họ thực vật, trong đó họ Apocynaceae có số loài đa dạng nhất có 7 loài, họ Lamiaceae có 6 loài, họ Euphorbiaceae có 5 loài, họ Araceae, Asteraceae và Moraceae cùng có 4 loài, kế đến là họ Amaryllidaceae, Araliaceae, Arecaceae, Cucurbitaceae, Myrtaceae, Rubiaceae và họ Rutaceae có 3 loài, các họ còn lại có từ 1 đến 2 loài. Cây cảnh có giá trị dược liệu khảo sát được ở các vườn kiểng đa dạng hơn hẳn so với các cây dược liệu có giá trị cảnh quan ứng dụng vào thiết kế thực tiễn ở Thảo Cầm Viên TP. Hồ Chí Minh (58 loài thuộc 41 họ thực vật) (Nguyen, 2009) và với số loài cây cảnh có tác dụng dược liệu được trồng ở các hộ gia đình (9 loài trồng làm thuốc, 4 loài vừa làm cảnh vừa làm thuốc) (Vu, 2012). Tuy vậy, so với các cây dược liệu hiện được ghi nhận ở nước ta thì số loài cây cảnh có dược tính chỉ chiếm 13,3\% trong số 901 loài thuốc nam (Do, 2004), do giới hạn đề tài chỉ khảo sát tập trung vào cây kiểng ở TP. Hồ Chí Minh. Các cây cảnh có giá trị dược liệu ở các vườn kiểng đa dạng và có thể đáp ứng ngay nhu cầu sử dụng của người dân.

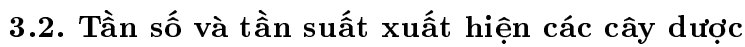 liệu ở các vườn kiểng}

Tần số và tần suất xuất hiện của các cây cảnh có giá trị dược liệu có sự khác nhau, loài có tần số/tần suất xuất hiện nhiều nhất cây Lưỡi Hổ (Sansevieria trifasciata parain var. laurentii (De Willd.) N.E.Brown) (72 lần $/ 73,5 \%$ ). Xuất hiện nhiều tiếp theo có những loài như Ngũ Gia Bì (Scheflera heptaphylla (L.) Frodin) và Thủy Trúc (Cyperus flabelliformis Rottb.) với (66 lần $/ 67,3 \%)$. Kế đến là các loài như
Vạn Niên Thanh (Aglaonema siamense Engl.) và Dâm Bụt (Hibiscus rosa sinensis L.) (51 lần $/ 52 \%)$. Những loài có tần suất xuất hiện ít nhất như: Đại Tướng Quân (Crimuum asiaticum L.), Mướp Đắng (Momordica charantia L.), Bầu (Langennaria siceraria (Molina) Standl.), Bướm Bạc (Mussaenda frondosa L.), Chè (Camellia sinensis (L). Kuntze), Sung (Ficus racemosa L.), Lộc Vừng (Barringtonia acutangula (L.) Gaertn), Nhất Mạt Hương (Plectranthus macranthus Hook.f.) (17 lần/17,3\%).

\subsection{Phân nhóm các cây cảnh có giá trị dược liệu}

Đề tài này thực hiện phân nhóm cây cảnh có giá trị dược liệu theo 2 cách:

(i) Phân nhóm theo đặc điểm hình thái: gồm 8 nhóm là cây gỗ $(23 \%)$, cây có hoa làm cảnh (19\%), cây có lá làm cảnh (12\%), dây leo (13\%), cây rau (8\%), cây thân cột $(6 \%)$, cây có thân mọng nước $(16 \%)$ và cây thủy $\sinh (3 \%)$.

(ii) Phân nhóm theo công dụng dược liệu của cây cảnh: dựa vào công dụng của các cây cảnh có dược tính được tra cứu theo Vo (2012), tác giả đã chia thành 8 nhóm là nhóm cây cảnh có tác dụng an thần trị mất ngủ, nhóm cây cảnh có tác dụng chữa bệnh phụ nữ, nhóm cây cảnh có tác dụng cầm máu, nhóm cây cảnh có thể dùng làm thực phẩm và dùng dưới dạng tươi sống, nhóm cây cảnh có tinh dầu, nhóm cây cảnh chữa các bệnh ngoài da, nhóm cây cảnh có tác dụng chữa cảm sốt và nhóm cây cảnh có tác dụng chữa các bệnh về đường hô hấp.

\subsection{Nhóm cây cảnh có tác dụng an thần, trị mất ngủ}

Có 8 loài có tác dụng trị an thần, mất ngủ và thuộc 8 họ thực vật khác nhau trong nhóm 5 nhóm hình thái là nhóm cây gỗ có cây Táo (Ziziphus mauritiana Lam.) và cây Chè, nhóm cây thân mọng nước có 2 cây là cây Đại Lá Tù (Plumeria obtusa L.) và cây Ngô Đồng Cảnh $(J a-$ tropha podagrica Hook.), nhóm cây thủy sinh có 2 cây là Sen (Nelumbo nucifera Gaertn.) và Súng (Nymphaea stellata Willd.), nhóm cây leo làm cảnh có một cây là Thiên Lý (Telosma cordata (Burm. f.) Merr.), nhóm cây hoa làm cảnh có cây Nhài (Jasminum sambac (L.), Ait).

Theo khảo sát, cây Táo có tần số lớn nhất (43 lần) rồi đến cây Nhài với 37 lần, tiếp đến cây Sen và cây Súng với 35 lần. 


\subsection{Nhóm cây cảnh có tác dụng chữa bệnh phụ nữ}

Nhóm này có 12 loài có tác dụng trị bệnh phụ nữ thuộc 9 họ thực vật khác nhau, trong đó họ Rubiaceae có nhiều loài nhất 3 loài là Trang Đỏ (Ixora coccinea L.), Trang Vàng (Ixora lutea Hutch.) và Hoa Hồng (Rosa chinensis Jacq.). Nhóm công dụng này có mặt ở 6 nhóm hình thái là nhóm cây hoa làm cảnh với 4 loài là Cẩm Chướng Gấm (Dianthus chinensis L.), Trang Đỏ, Trang Vàng và cây Hoa Hồng, nhóm cây rau với 3 loài là Nha Đam (Alove vera (L.) Burm.f.), Ngải Cứu (Artemisia vulgaris L.) và Diếp Cá (Houttuynia cordata Thunb.), nhóm cây leo làm cảnh có cây Đăng Tiêu (Campsis radicans Seem.), nhóm cây lá làm cảnh với 2 loài là Thiên Niên Kiện (Homalomena occulta (Lour.) Schott.) và Trạng Nguyên (Euphorbia pulcherrima Willd. ex Klotzsch), nhóm cây thân cột có cây Huyết Dụ (Cordyline fruticosa L.).

Cây Trang Đỏ có tần số lớn nhất với 66 lần, tiếp theo là Trạng Nguyên (35 lần) và cây Nha Đam với 28 lần.

\subsection{Nhóm cây cảnh có tác dụng cầm máu}

Trong nhóm này, có 5 loài có tác dụng cầm máu thuộc 5 họ thực vật khác nhau và được chia thành 4 nhóm hình thái là nhóm cây hoa làm cảnh và cây thân cột có số loài nhiều nhất (2 loài) lần lượt là các cây như Mào Gà Đỏ (Celosia argentea L. var. cristata) và Hoa Hồng; Cau Kiểng Vàng (Chrysalidocarpus lutescens $\mathrm{H}$. Wendl.) và Huyết Dụ. Nhóm cây thân mọng nước có cây Sống Đời (Kalanchoe pinnata (Lam.) Pers.) và nhóm cây thủy sinh có cây Sen. Cây Mào Gà Đỏ gặp nhiều nhất với 43 lần, cây Cau Kiểng Vàng (37 lần), cây Sống Đời với 35 lần.

\subsection{Nhóm cây cảnh làm thực phẩm và dùng dưới dạng tươi sống}

Trong nhóm này có 24 cây có thể dùng làm thực phẩm và dùng dưới dạng tươi sống thuộc 20 họ thực vật khác nhau. Trong đó, họ Asteraceae gồm các loài là Rau Ngổ (Enydra fluctuans Lour.) và loài $\mathrm{Ngải} \mathrm{Cứu,} \mathrm{họ} \mathrm{Cucurbitaceae} \mathrm{gồm}$ 2 loài là Mướp (Luffa cylindrical (L.) M.Roem.) và Mướp Đắng, họ Lamiaceae với 2 loài Tần Lá Dày (Coleus amboinicus Lour.) và Tía Tô (Perilla frulescens (L.) Britton). Các cây thuộc 7 nhóm hình thái là nhóm cây rau như: Rau Ngót
(Sauropus androgynus (L.) Merr.), Diếp Cá, Nha Đam, Cây Ớt (Capsicum frutescens L.), Mồng Tơi (Basella alba L.), Ngải Cứu, Tía Tô, Rau Răm (Polygonum odoratum Lour.), Rau Ngổ và Mã Đề (Plantago major L.); nhóm cây gỗ có các cây Cóc Chua (Spondias pinnata (L.f.) Kurz.), Lộc Vừng, Ổi (Psidium guajava L.), Táo, Quất (Fortunella japonica Thunb.) và cây Xirô (Carissa carandas L.); nhóm cây leo làm cảnh có 3 cây là Mướp, Mướp Đắng và cây Nho (Vitis vinifera $\mathrm{L}$.); nhóm cây thân mọng nước có 2 loài là Thài Lài Tía (Zebrina pendula Schnizl.) và Tần Lá Dày; nhóm cây hoa làm cảnh, lá làm cảnh và thân cột có 1 loài lần lượt là cây Mua (Melastoma candidum D.Don), Cô Tòng Đuôi Lươn (Codiaeum variegatum (L.) Blume) và Đu Đủ (Carica papaya L.). Cây Ổi có tần số lớn nhất (48 lần), tiếp theo cây Thài Lài Tía, cây Táo và cây Quất (32 lần).

\subsection{Nhóm cây cảnh có tinh dầu}

Nhóm này có 9 cây có tinh dầu thuộc 6 họ thực vật khác nhau. Trong đó, họ Lamiaceae có nhiều loài nhất với 4 loài Hương Thảo (Rosmarinus officinalis L.), Tần Lá Dày, Bạc Hà (Mentha arvensis L.) và Nhất Mạt Hương. Về mặt hình thái, nhóm này đa phần thuộc nhóm cây lá làm cảnh (Bạc Hà, Hương Thảo và Lá Dứa (Pandanus amaryllifolius Roxb.)) và nhóm cây gỗ (Chanh (Citrus aurantifolia (Christm. \& Panzer) Swingle), Bưởi (Citrus grandis L.) và Quất), nhóm cây thân mọng nước với 2 loài cây là Tần Lá Dày và Nhất Mạt Hương, nhóm cây hoa làm cảnh và cây rau có 1 loài lần lượt là cây Nhài và Cây Sả (Cymbopogon citratus (DC.) Stapf). Theo khảo sát, cây gặp lại nhiều nhất là cây Hương Thảo (49 lần), cây Nhài, (37 lần), xuất hiện nhiều tiếp theo là cây Quất.

\subsection{Nhóm cây cảnh chữa các bệnh ngoài da}

Có 29 loài có tác dụng trị các bệnh ngoài da thuộc 22 họ thực vật khác nhau. Trong đó, họ Araliaceae có 3 loài như Ngũ Gia Bì, Rau Má Thái (Hydrocotyle bonariensis Comm.ex Lam.) và Đinh Lăng Đuôi Phụng (Polyscias fruticosa L.H.Bailey), 5 họ có 2 loài thuộc nhóm chữa bệnh ngoài da là họ Begoniaceae, Cucurbitaceae, Moraceae, Myrtaceae, Rubiaceae, các họ còn lại có 1 loài. Về hình thái, nhóm cây gỗ chiếm số lượng nhiều nhất với 10 loài (Lộc Vừng, Đa Búp Đỏ (Ficus elastica Roxb. ex Horn.),...); nhóm cây 
leo làm cảnh gồm 7 loài như Thiên Lý, Đậu Biếc (Clitoria ternatea L.), Huỳnh Anh (Allamanda cathartica L.), Tóc Tiên (Quamoclit pennata (Lam.) Bojer) và Đăng Tiêu; nhóm cây thân mọng có 4 loài như Đại Tướng Quân, Xương Khô (Euphorbia tirucalli L.), Thu Hải Đường (Begonia semperflorens Link et Otto); nhóm cây hoa làm cảnh và cây rau cùng có 3 loài; nhóm cây thân cột và cây thủy sinh chỉ có 1 loài. Cây có tần số xuất hiện nhiều nhất là cây Trang Đỏ và Ngũ Gia Bì (66 lần), tiếp đến là cây Dâm Bụt, Mít (Artocarpus heterophyllus Lam.) với 51 lần, tiếp theo cây Đinh Lăng Đuôi Phụng và cây Ổi 48 lần.

\subsection{Nhóm cây cảnh có tác dụng chữa cảm sốt}

Theo kết quả thống kê, có 19 loài có tác dụng trị cảm sốt thuộc 16 họ thực vật khác nhau. Trong đó họ Araliaceae có nhiều loài nhất với 3 loài Ngũ Gia Bì, Rau Má Thái, Đinh Lăng Đuôi Phụng và họ Lamiaceae có 2 loài Tía Tô và Bạc Hà. Các loài cây phân bố ở cả 8 nhóm hình thái, trong đó nhóm cây gỗ chiếm số lượng nhiều nhất với 7 loài như Bàng (Terminalia catappa L.), Đa Búp Đỏ, Chanh, cây Chè...; nhóm cây rau có 4 loài gồm Tía Tô, Rau Má Thái, Mã Đề và cây Sả; nhóm cây có lá làm cảnh với 3 loài Môn Đốm (Caladium bicolor (Aiton) Vent.), Trắc Bách Diệp (Thuja orientalis L.) và Bạc Hà; các nhóm cây còn lại có 1 loài. Cây được gặp lại nhiều nhất là cây Ngũ Gia Bì, xuất hiện nhiều tiếp theo cây Đinh Lăng Đuôi Phụng.

\subsection{Nhóm cây cảnh có tác dụng chữa các bệnh về đường hô hấp}

Có 20 loài cây cảnh có tác dụng chữa các bệnh về đường hô hấp thuộc 20 họ thực vật khác nhau và nằm trong 7 nhóm hình thái. Nhóm cây thân mọng nước chiếm số lượng nhiều nhất với 5 loài như Lẻ Bạn (Tradescantia dícolor L'Her), Lưỡi Hổ, Đại Tướng Quân... Các nhóm cây có 3 loài là nhóm cây gỗ, lá làm cảnh, hoa làm cảnh và cây leo làm cảnh, kế đến nhóm cây rau có 2 loài và nhóm cây thân cột có 1 loài. Các cây có tần số lớn nhất gồm Lưỡi Hổ, Vạn Niên Thanh và Dâm Bụt.

Đề tài cũng nhận thấy, trong mỗi nhóm công dụng của các cây cảnh dược liệu đều có những nhóm hình thái đặc trưng như: cây cảnh có thể dùng dưới dạng tươi sống thuộc nhóm cây rau (10 loài/24 loài), cây cảnh có tác dụng chữa cảm sốt thì thuộc nhóm hình thái cây gỗ nhiều nhất (10 loài/19 loài) và cây có tác dụng chữa các bệnh về đường hô hấp thuộc nhóm thân mọng nước là đa số (5 loài/20 loài).

Ngoài việc ứng dụng và phối kết theo các tiêu chí hình dáng, màu sắc, tỷ lệ và theo mùa như cây cảnh thông thường, nhóm tác giả kết hợp đặc điểm hình thái, sinh lý và đặc điểm về dược tính của cây đề xuất một số nguyên tắc ứng dụng cây cảnh dược liệu trong thiết kế sân vườn như sau: các cây có tinh dầu giúp tinh thần thư thái nên được bố trí trong vườn nghỉ ngơi hoặc khu thưởng trà, khu tập yoga, thiền; cây có dáng đẹp và hoa thơm nhẹ được bố trí trong vườn ngắm cảnh; khu vườn rau vừa cung cấp một số loại rau phổ biến theo sở thích gia chủ vừa có thể được xem như một tiểu cảnh trang trí sân vườn, ngoài ra, đây còn có thể là nơi trồng một số loài cây có tác dụng chữa bệnh thông thường; các cây gia vị có thể trồng cạnh khu tổ chức tiệc nhỏ ngoài trời.

Ứng dụng các loài cây cảnh dược liệu đã khảo sát được vào thiết kế 2 mẫu sân vườn biệt thự nhà phố với các nguyên tắc thiết kế cảnh quan và được thực hiện theo yêu cầu của gia chủ là người yêu cây dược liệu và mong muốn trang trí sân vườn bằng những loài cây này.

\subsubsection{Mẫu sân vườn 1}

Mẫu sân vườn 1 là mẫu sân vườn nhà phố tọa lạc tại đường Xuân Thủy, phường An Phú, Quận 2, TP.HCM có tổng diện tích là $300 \mathrm{~m}^{2}$ trong đó, diện tích ngôi nhà là $110 \mathrm{~m}^{2}$ còn lại là diện tích sân vườn $190 \mathrm{~m}^{2}$. Khảo sát hiện trạng cho thấy bên phải và bên trái khu đất tiếp giáp các căn nhà phố khác, phía sau khu đất là diện tích đất chưa xây dựng.

Nhà phố này có phong cách thiết kế hiện đại, sử dụng gam màu trắng là chủ đạo. Chủ nhà thích vườn mang hơi thở hiện đại nhưng vẫn giữ được nét truyền thống Việt Nam. Do đó, sân vườn được thiết kế gồm 3 khu là khu nhà ở, khu ngắm cảnh và khu nghỉ ngơi. Trong đó, vườn ngắm cảnh có diện tích $10 \mathrm{~m} \times 7,4 \mathrm{~m}$ nằm ở mặt trước của ngôi nhà, vườn nghỉ ngơi có diện tích $10 \mathrm{~m} \times 7 \mathrm{~m}$ nằm ở mặt sau ngôi nhà (Hình 1).

Vườn ngắm cảnh bao gồm sân đậu xe, lối đi và tiểu cảnh. Thiết kế tiểu cảnh nước với dòng thác nhỏ đổ xuống mặt nước tạo nên những âm thanh róc rách làm cho không gian trở nên đa dạng và sống động, bên trong hồ nước bố trí các bồn 


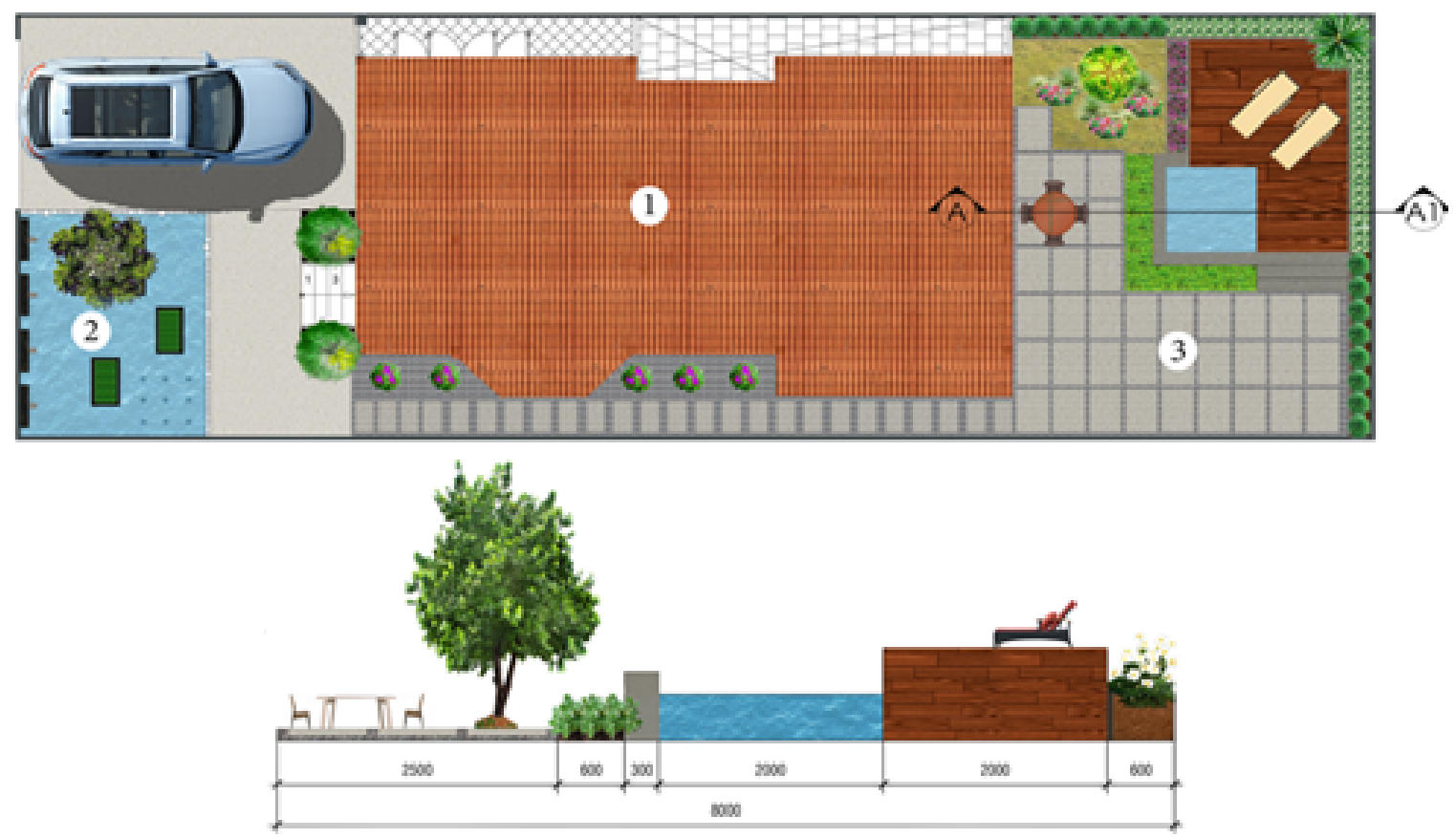

Hình 1. Mặt bằng tổng thể sân vườn nhà và mặt cắt vườn nghỉ ngơi.

để trồng cây. Cây được dùng cho tiểu cảnh gồm Thủy Trúc, Đại Lá Tù và Bạch Trinh Biển $(H y-$ menocallis littoralis (Jacq.) Salisb.). Điểm nhấn chính là cây Đại Lá Tù với dáng cây đẹp và hoa thơm nhẹ. Dòng chảy của nước kết hợp với màu xanh của cây lá và màu trắng của hoa tạo cho con người cảm giác mát mẻ. Gia chủ có thể ngắm cảnh từ trong nhà thông qua cửa kính phòng khách, khách đến chơi nhà có thể nghe được âm thanh vui tai của nước và ngắm hoa Bạch trinh nở quanh năm.

Tiểu cảnh sân sau là vườn nghỉ ngơi (Hình 2) được thiết kế theo phong cách hiện đại, tận dụng khoảng không gian này để làm nơi vui chơi, nghỉ ngơi của gia đình với sàn gỗ ngoài trời có ghế nằm nghỉ hóng mát. Bồn hoa Cúc Bách Nhật (Gomphrena globosa L.) dọc theo sàn gỗ làm cho sàn gỗ bớt đơn điệu khô khan. Hồ nước động phía trước sàn gỗ làm cho không gian trở nên sinh động hơn. Vì là khu nghỉ ngơi nên cây trồng ở khu này chủ yếu là các cây có tinh dầu giúp tinh thần thư thái hơn sau mỗi ngày làm việc như cây Nhài, Nhất Mạt Hương, Bưởi kết hợp với các cây Mạch Môn (Ophipogon japonicus 'Kyoto Dwarf'), Cúc Bách Nhật, Agao mỹ (Agave americana L.), Dừa Cạn (Catharanthus roseus (L) G.Don).

Vì bao quanh nhà phố là tường rào đóng kín

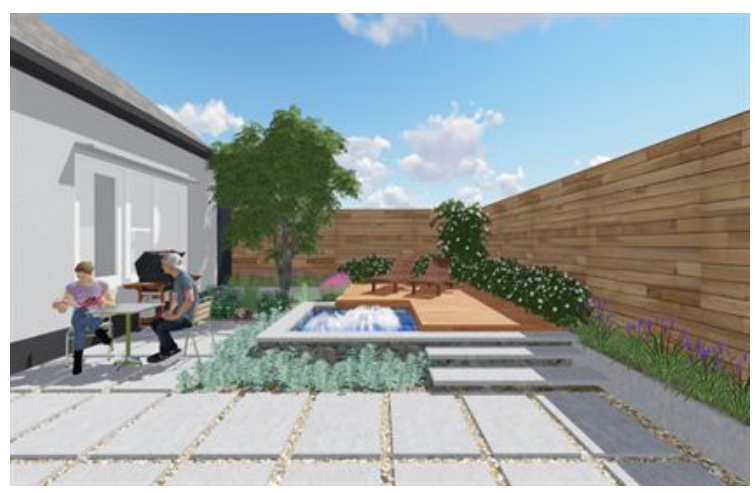

Hình 2. Phối cảnh sân vườn nghỉ ngơi.

nên tác giả bố trí một số loài cây xanh để góc tường bớt khô cứng, nặng nề. Màu trắng của hoa nhài trồng trong bồn ôm chân tường đem lại không khí tươi mát cho sân vườn. Ngoài ra, các cây dùng ở vườn sau còn có tác dụng chữa các bệnh ngoài da, tim mạch và các bệnh về đường hô hấp. Danh mục cây xanh bố trí trong mẫu vườn 1 thể hiện ở Bảng 1.

\subsubsection{Mẫu sân vườn 2}

Mẫu sân vườn 2 là mẫu sân vườn biệt thự tọa lạc tại 430K Tây Hòa, Phước Long A, quận 9, 


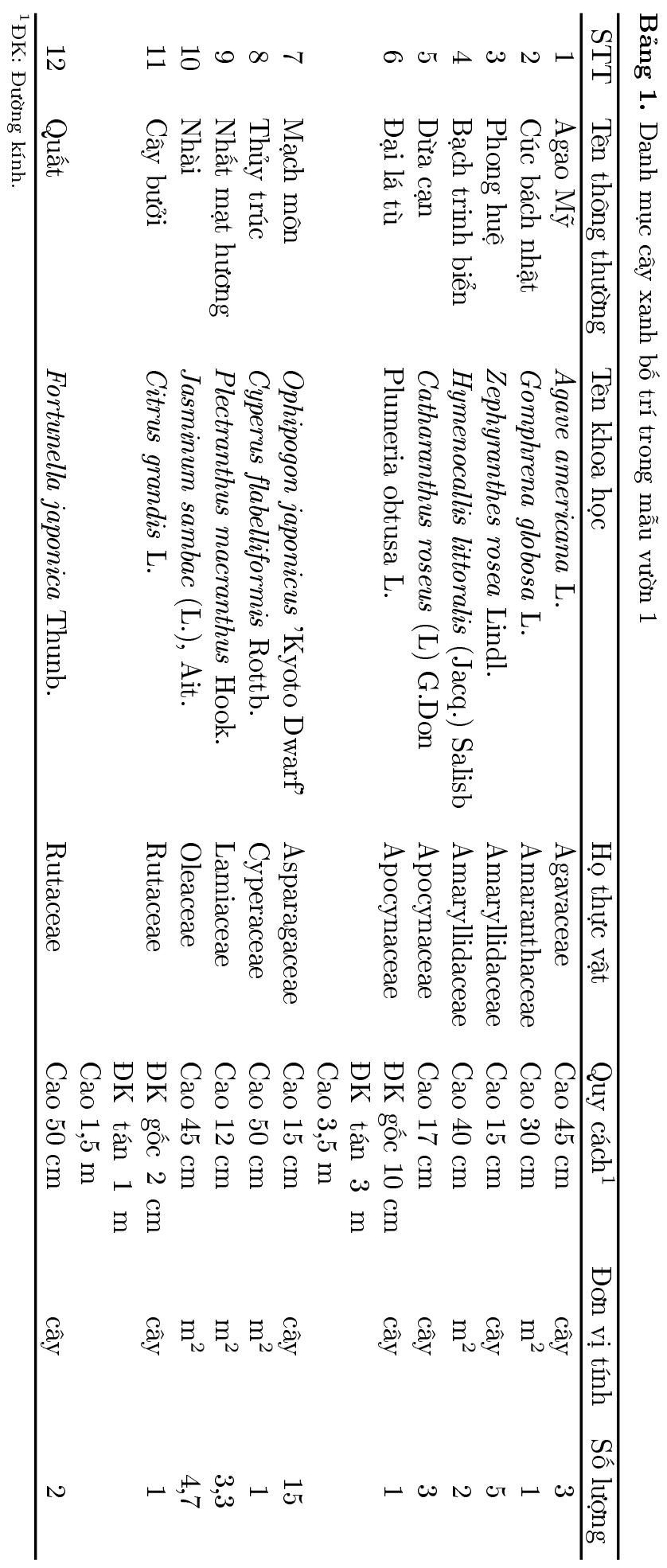




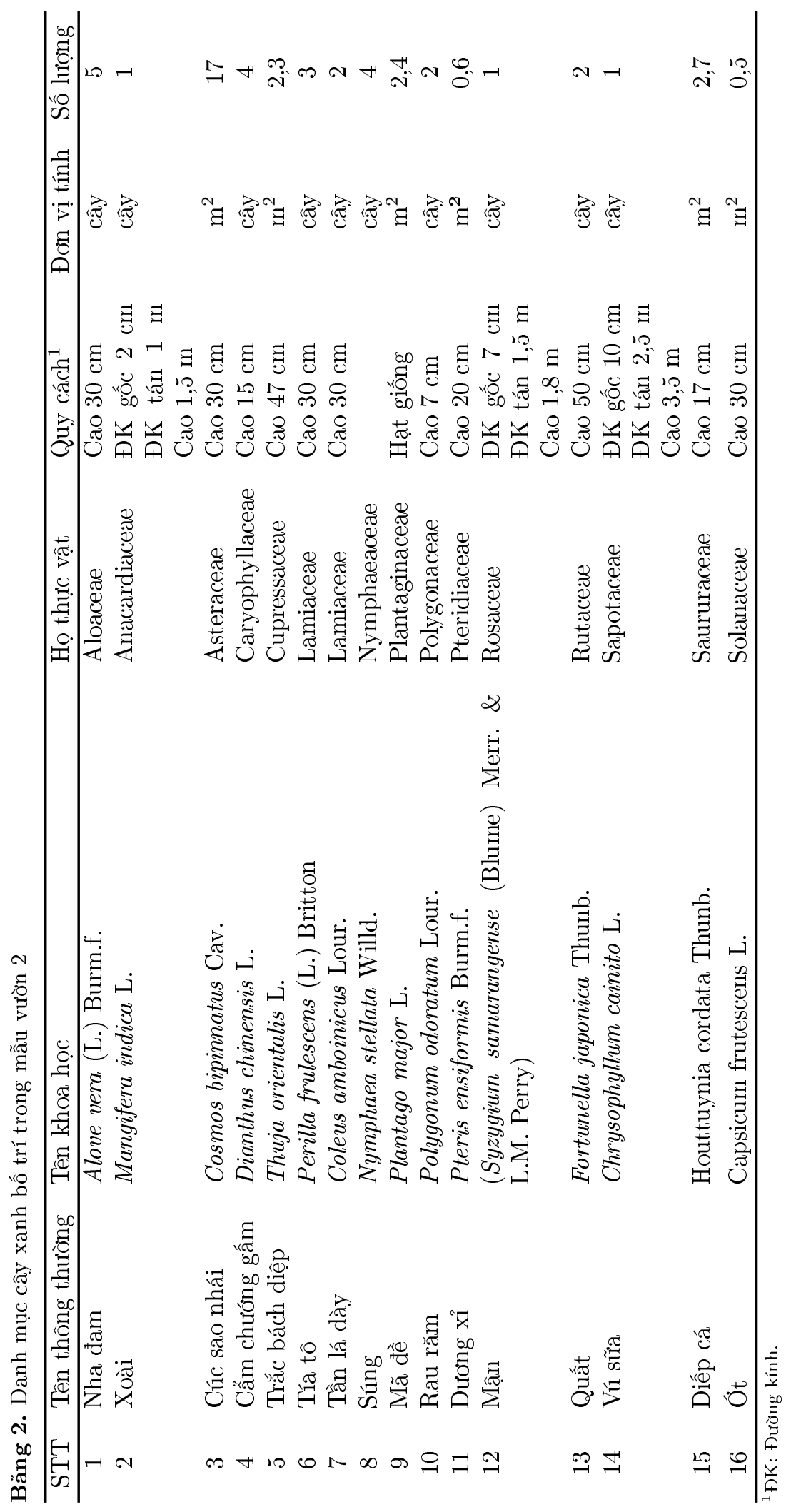


TP.HCM, có tổng diện tích là $253 \mathrm{~m}^{2}$ trong đó, diện tích ngôi nhà là $76 \mathrm{~m}^{2}$, còn lại là diện tích sân vườn $177 \mathrm{~m}^{2}$. Kiến trúc ngôi nhà được thiết kế theo xu hướng hiện đại nên cảnh quan sân vườn cũng thiết kế theo phong cách này. Chủ nhà rất yêu thích yếu tố nước nên diện tích mặt nước chiếm phần lớn sân vườn.

Sân vườn được thiết kế gồm 5 khu là khu nhà ở, khu ngắm cảnh, vườn rau, khu tiểu cảnh và khu thưởng trà. Trong đó khu ngắm cảnh nằm ở sân trước ngôi nhà, vườn rau nằm ngay bên phải biệt thự gần phòng ăn, khu uống trà nằm phía sau ngôi nhà, khu tiểu cảnh nằm bên trái biệt thự (Hình 3).

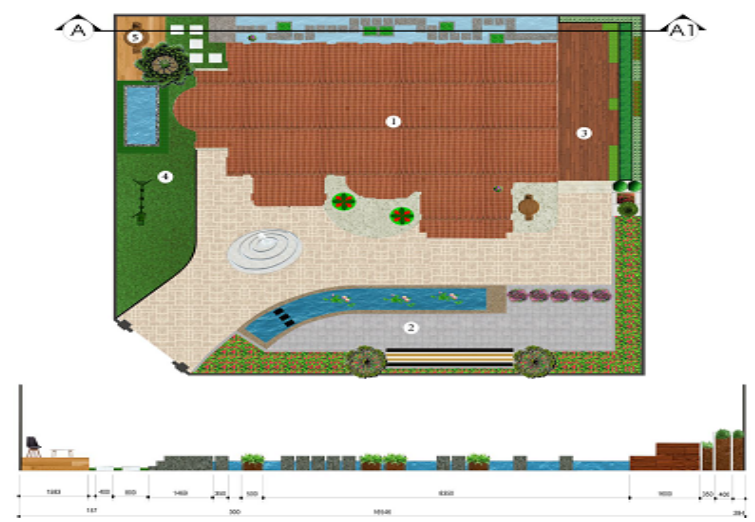

Hình 3. Mặt bằng tổng thể sân vườn biệt thự và mặt cắt khu thưởng trà.

Khu ngắm cảnh có điểm nhấn là đài phun nước dạng xoắn ốc. Hồ nước tĩnh trồng hoa sen bên phải để phân chia không gian lối đi và khu ngồi ngắm cảnh. Chủ nhà có thể ngồi nghỉ ngơi, ngắm cảnh bên dưới giàn leo. Khu này trồng các cây bóng mát như Vú Sữa (Chrysophyllum cainito L.) và Mận (Syzygium samarangense (Blume) Merr. \& L.M.Perry).

Vườn rau (Hình 4) tiếp giáp với phòng ăn, với diện tích không lớn của khu vườn nên tác giả dã thiết kế thành vườn theo dạng tầng bậc với một số loại rau như: Diếp Cá, Mã Đề, ớt,...Các cây này ngoài công dụng là những cây rau sử dụng trong đời sống hằng ngày còn có những công dụng dược liệu khác như cây Diếp Cá trị táo bón, viêm đau mắt đỏ, viêm tai giữa..., cây Mã Đề dùng chữa cảm lạnh ho, viêm phế quản.... Xen kẽ các bồn để trồng rau là các chậu trồng Nha Đam, Tía Tô, Tần Lá Dày.

Sàn gỗ lộ thiên được bố trí ngay cạnh bên cây Vú Sữa. Lối đi dẫn đến sàn gỗ bằng những phiến

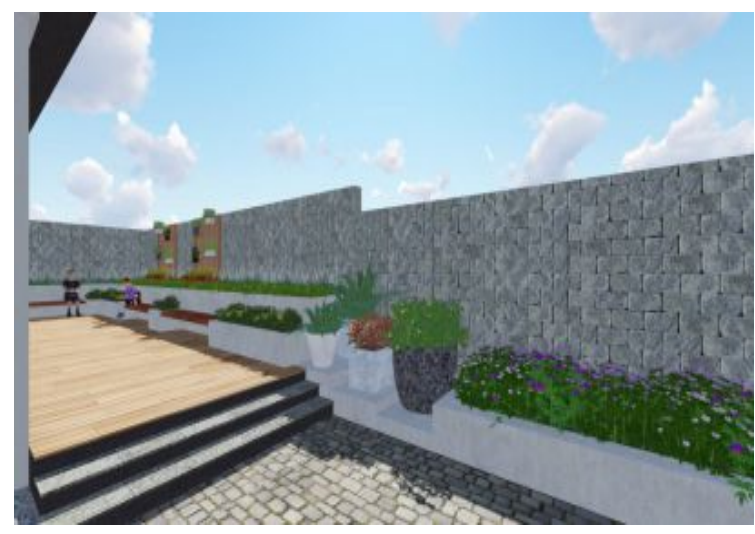

Hình 4. Phối cảnh vườn rau.

gạch vuông màu trắng nổi bật trên nền xanh của thảm cỏ là một yếu tố tạo hình quan trọng của sân vườn (Hình 5).

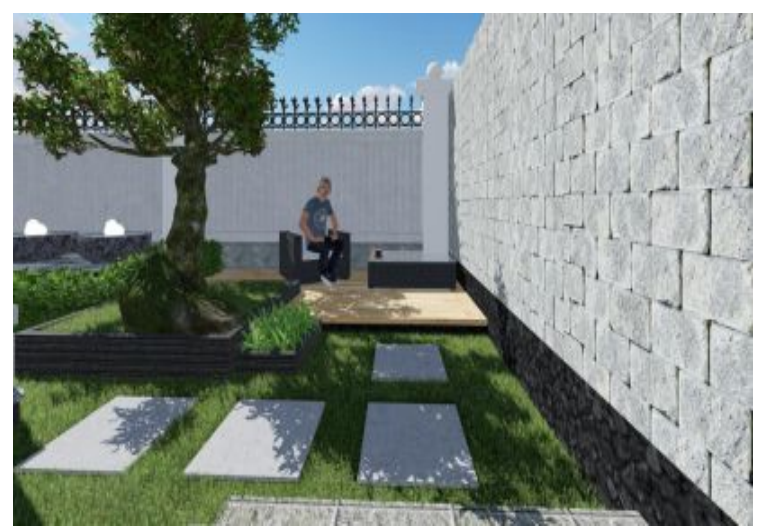

Hình 5. Phối cảnh khu uống trà.

Góc nhìn từ cổng vào là thảm cỏ được bố trí xích đu để ngồi nghỉ ngơi ngắm nhìn cảnh ở sân trước. Phía xa là tiểu cảnh nước chảy tràn, thiết kế bố trí cây Trắc Bách Diệp bên dưới tiểu cảnh để che đi phần kết cấu bên trong của tiểu cảnh, cây Trắc Bách Diệp có dược tính là cầm máu, chữa ho sốt và lợi tiểu. Danh mục cây xanh bố trí trong mẫu vườn 2 thể hiện ở Bảng 2 .

\section{Kết Luận}

Đề tài đã khảo sát và định danh được 120 loài cây cảnh có giá trị dược liệu thuộc 69 họ thực vật tại các vườn kiểng ở quận Gò Vấp, quận 7 , quận 10, quận Thủ Đức, quận Tân Bình, Thành phố Hồ Chí Minh. Qua phân tích và tổng hợp số liệu, đề tài đã xác định được tần số và tần suất xuất hiện của các loại cây cảnh trên. Việc phân nhóm 
các cây cảnh có giá trị dược liệu theo hình thái và theo công dụng đã hỗ trợ ứng dụng trong thiết kế 2 mẫu sân vườn theo phong cách vườn hiện đại với các bản vẽ mặt bằng, mặt cắt và phối cảnh.

Cần có những nghiên cứu khảo sát sâu rộng hơn điều tra về các cây cảnh dược liệu không chỉ tại Thành phố Hồ Chí Minh. Đồng thời, cần tìm hiểu nhu cầu cụ thể của người dân về việc sử dụng cây cảnh dược liệu.

\section{Tài Liệu Tham Khảo (References)}

Abdullah, I. N. (2015). Identification of ornamental plant which possess medicinal function based on its leaf shape, texture, and color features. (Unpublished doctoral dissertation). School of Science and Engineering, Saga University, Indonesia.

Do, L. T. (2004). Vietnam's medicinal plants and herbs. Ha Noi, Vietnam: Medical Publshing House.

Dung, T. N. (2017). Visit the Go Vap flower village on Tet holiday. Retrieved February 10, 2017, from http://cand.com.vn/Xa-hoi/Tham-lang-hoa-GoVap-khi-Xuan-ve-172936/.

Gia, B. (2016). The 8X Da Lat generation successfully started its business from planting. Retrieved February 25, 2017, from https://baodautu.vn/8x-da-lat-khoinghiep-thanh-cong-tu-trong-cay-kieng-duoc-lieud50460.html.

Le, T. P., \& Pham, C. K. (1993). Urban trees. Ha Noi, Vietnam: Construction Publishing House.

Min, B. C., Omar-Hor, K., \& Chow Lin, O. Y. (2003). 1001 Garden plants in Singapore. Singapore: Nation Parks Board.

Nguyen, D. H. (2003a). Beautiful ornamental plants used as medicinal herbs or treatments for disease. Ha Noi, Vietnam: Ha Noi Publishing House.

Nguyen, D. H. (2003b). Ornamental plants - medicinal herbs in school grounds. Ha Noi, Vietnam: Vietnam Education Publishing House.

Nguyen, M. T. N. (2009). Identification of medicinal plants with landscape values in the Sai Gon zoo and botanical gardens of Ho Chi Minh City. (Unpublished bachelor thesis). Nong Lam University, Ho Chi Minh City, Vietnam.
Pham, H., Bui, C. V., \& Le, T. V. (2000). Medicinal plants, remedies, and proprietary medicines. Ha Noi, Vietnam: Medical Publishing House.

Pham, H. H. (2002). An illustrated Flora of Vietnam. Ho Chi Minh City, Vietnam: Tre Publishing House.

TDPC (Thu Duc District People's Committee). (2016). Planning for development of ornamental plants in Thu Duc district in the period of 2016 - 2020. Retrieved April 18, 2019, from http://quantri.thuduc.hochiminhcity.gov.vn//Data/ UBND/thuduc/Attachments/VB\%20ch\%E1\%BB\%89 \%20\% C4\%91\%E1\%BA\%A1o/Th\%C3\%A1ng\%203/67110316.pdf.

Thu, P. (2017). Vietnamese medicine plants have a chance of reaching the world market. Retrieved June 15, 2017, from https://www.vietnamplus.vn/duoclieu-viet-nam-co-co-hoi-vuon-ra-thi-truong-thegioi/442613.vnp.

Tran, H. (1998). Trees and ornamental plants in Sai Gon - Ho Chi Minh city. Ha Noi, Vietnam: Agricultural Publishing House.

Tran, H. (2016). Viet Nam ornamental plants resources, Volumne No. 2. Ha Noi, Vietnam: Agricultural Publishing House.

Tran, T. T. H., Cusi, M., Ta, S. M., Nguyen, C. D. T., Eugui, D. V., Dent, R., \& Durleva, M. (2016). The interface between access and benefit-sharing rules and BioTrade in Viet Nam. United Nations Conference on Trade and Development. Retrieved January 7, 2019, from http://unctad.org/en/PublicationsLibrary/webditcted 2016d9_en.pdf.

Vo, C. V. (2012). Dictionary of Vietnamese medicinal plants. Ha Noi, Vietnam: Medical Publishing House.

$\mathrm{Vu}, \mathrm{L} . \mathrm{T} . \mathrm{T} .(2012)$. Investigation of medicinal bonsai plants in Ho Chi Minh City and coordinating them in the landscape. (Unpublished bachelor thesis). Nong Lam University, Ho Chi Minh City, Vietnam. 